\title{
Cysteinyl leukotrienes in asthma: current state of therapeutic evaluation
}

Ian K Taylor

Among the many inflammatory mediators implicated in asthma, the cysteinyl leukotrienes $\left(\mathrm{LTC}_{4}, \mathrm{LTD}_{4}\right.$ and $\left.\mathrm{LTE}_{4}\right)$ - peptidolipid conjugates formed following lipoxygenation of arachidonic acid - have attracted much attention. ${ }^{1-6}$ They are generated in vitro following immunological and non-immunological challenge from lung tissue ${ }^{7}$ and purified mast cells, ${ }^{8}$ monocytes/macophages, ${ }^{5}$ and eosinophils. ${ }^{9}$ The biological actions of the cysteinyl leukotrienes have now been extensively characterised; within the lung they can impair mucociliary clearance, enhance mucus secretion, and facilitate changes in pulmonary vascular permeability. ${ }^{1-6}$ Their potent spasmogenic properties on human airway smooth muscle both in vitro and in vivo have similarly been comprehensively documented ${ }^{10-14}$ and further evidence suggests that they increase bronchial hyperresponsiveness. ${ }^{15-18}$ These properties, which reproduce some of the functional and histological features of clinical asthma, have generated considerable interest in the quantification in vivo of cysteinyl leukotrienes in asthmatic subjects. In addition, the development and emergence of potent end organ receptor antagonists and synthesis inhibitors have enabled an insight into the role of these mediators in asthma.

Whilst a role for leukotrienes has been suggested in a wide variety of other diseases including hepatorenal syndromes, myocardial ischaemia, and inflammatory conditions of the bowel, skin and joints, ${ }^{3}$ this article reviews the evidence of their involvement principally in asthma and, to a lesser extent, allergic rhinitis. Only clinical studies in asthmatic patients will be considered, to the exclusion of animal and in vitro data, and will comprise three parts: (1) a review of those studies in which cysteinyl leukotriene generation in vivo has been demonstrated either (a) following administration to the airway of indirect bronchoconstrictor challenges, (b) during clinical disease exacerbations, or (c) under basal conditions; (2) those studies in which there have been attempts pharmacologically to modulate cysteinyl leukotriene generation or to attenuate their end organ effects in the airway under (a) unprovoked conditions, (b) following bronchoprovocative stimuli, or (c) in chronic persistent asthma; and (3) most importantly, given the current available evidence, a critical evaluation of the therapeutic potential of these drugs in human asthma.

\section{Evidence for cysteinyl leukotriene release in asthma}

It is axiomatic that the most suitable place to measure inflammatory mediators is at their putative site of action. The nose is readily accessible to evaluate mediator production and cysteinyl leukotrienes have been quantified in nasal secretions following local allergen challenge. ${ }^{1920}$ The use of the fibreoptic bronchoscope coupled with bronchoalveolar lavage (BAL) now permits similar studies in the lower respiratory tract and abundant evidence exists on cellular profiles, cellular activation status, and secretory products within the asthmatic airway. Whilst initial reservations over the safety and tolerability of such procedures were expressed, there is now general acceptance of their use in asthmatic subjects with a wide spectrum of disease severity, ${ }^{21}$ although doubts remain over interpretation of BAL solute data. ${ }^{22}$ Notwithstanding these reservations, increased quantities of cysteinyl leukotrienes have been recovered from BAL fluid both in patients with chronic persistent asthma ${ }^{2324}$ and following bronchoprovocation. ${ }^{2526}$ Plasma sampling and interpretation of data are less problematic, but plasma concentrations of proinflammatory mediators are, in many cases, exceedingly low, making detection and quantification difficult. Furthermore, invasive sampling may result in ex vivo generation of mediators secondary to activation and repeated measurements are required to give a time integrated insight of their production.

Biochemical analysis of urine, however, circumvents many of these problems. In the absence of renal synthesis, urinary mediator (or metabolite) levels will reflect plasma levels. Urine collections are easy to perform, are noninvasive and, because urine is essentially free of cells, the potential problem of ex vivo production of mediators is minimised. In humans, $\mathrm{LTE}_{4}$ is the stable bioconversion product of cysteinyl leukotriene metabolism in the lung, ${ }^{27}$ and numerous studies ${ }^{28-32}$ have now evaluated the metabolism, elimination, and pharmacodynamics of $\mathrm{LTE}_{4}$ excretion into the urine 
following either intravenous infusion of $\mathrm{LTC}_{4}{ }^{2829}$ and $\mathrm{LTE}_{4}{ }^{30}$ or inhalation of $\mathrm{LTD}_{4} \cdot{ }^{3132}$ Overall, these studies have demonstrated the rapid excretion into urine of $\mathrm{LTE}_{4}$ - either as an intact molecule or following enzymatic conversion from $\mathrm{LTC}_{4}$ and $\mathrm{LTD}_{4}$ - within four hours of either systemic administration or pulmonary inhalation. In the absence of either renal or hepatic dysfunction, measurement of urinary $\mathrm{LTE}_{4}$ excretion may be used to assess endogenous whole body cysteinyl leukotriene production in vivo in man, and this has been utilised in numerous studies both in the laboratory and in clinical asthma.

EVIDENCE OF CYSTEINYL LEUKOTRIENE RELEASE FOLLOWING INDIRECT CHALLENGE

\section{Allergen challenge}

Activation of mast cells classically by IgE-dependent mechanisms results in release of inflammatory mediators such as histamine, prostaglandin $\mathrm{D}_{2}$ and the cysteinyl leukotrienes, and it is the end organ response to these mediators that accounts for many of the features of the immediate bronchial response to inhaled allergen. Several studies have shown increased levels of urinary $\mathrm{LTE}_{4}$ excretion during early allergen-invoked bronchoconstriction. ${ }^{32-38}$ These data complement those obtained from BAL analysis following segmental allergen challenge to the lung ${ }^{26}$ and also following nasal allergen provocation. ${ }^{19203940}$ By contrast, comparable elevations in urinary $\mathrm{LTE}_{4}$ excretion during later allergen-invoked bronchoconstrictor responses are equivocal and have proved more difficult to interpret despite the demonstration of these products locally in the lung. ${ }^{25}$ It is not clear from these observations during later allergen-invoked bronchoconstriction whether de novo cysteinyl leukotriene synthesis and release is occurring from cells such as eosinophils recruited to the airway, or the end organ response is consequent upon prior liberation of cysteinyl leukotrienes from mast cells during the earlier stages of allergen-provoked bronchoconstriction. This issue has still not been unequivocally clarified, even with the demonstration of significant attenuation of late allergen-induced bronchoconstriction by potent cysteinyl leukotriene receptor antagonists, ${ }^{41}$ but is worthy of further critical analysis.

\section{Exercise and cold air challenge}

Exercise is a common stimulus of bronchoconstriction in asthmatic subjects, although the exact pathogenic sequence of events underlying its causation remains unclear. Several mechanisms have been proposed, including mast cell mediator release secondary to respiratory water loss, and hyperosmolar provocation and vascular phenomena provoking oedema formation within the airway wall. Data concerning the participation of inflammatory mediators, particularly cysteinyl leukotrienes, in either the maintenance or induction of the exercise-induced bronchoconstriction are conflicting. A number of studies have shown no increase in cysteinyl leukotriene concentrations in either plasma, ${ }^{42} \mathrm{BAL}$ fluid, ${ }^{43}$ or urine ${ }^{3644}$ following exercise challenge. Similarly, inhalation of cold air is not associated with increased urinary eicosanoid production (GW Taylor, unpublished data). By contrast, a study in children did show a modest increase in urinary LTE $_{4}$ excretion $^{45}$ and small but significant increases in cysteinyl leukotrienes have been demonstrated in BAL fluid after hyperventilation-induced bronchoconstriction. ${ }^{46}$ However, the most compelling evidence for a role for the cysteinyl leukotrienes in exerciseinduced asthma (and, indeed, the bronchoconstriction invoked by hyperventilation of cold dry air which is believed to share the same mechanism) are the numerous studies which have shown amelioration of airways limitation either by selective blockade of the 5-lipoxygenase enzyme ${ }^{47}$ or by selective end organ receptor blockade. ${ }^{48-51}$

\section{Platelet activating factor (PAF) challenge}

The role of the ether-linked alkylphospholipid platelet activating factor (PAF) in asthma has attracted much attention although its precise role in the pathogenesis of asthma is not clear. In common with other inflammatory mediators, PAF is capable of reproducing many of the functional and histological features seen in asthma both in vivo and in vitro, including microvascular leakage, bronchoconstriction, and inflammatory cell activation. Despite causing bronchoconstriction following inhalation in humans, ${ }^{52-54}$ PAF does not possess direct contractile effects on human airway smooth muscle strips in cell-free media in vitro, ${ }^{55}$ suggesting that some of its function in vivo may be mediated indirectly through the release of secondary mediators. In support of this, the generation of leukotrienes in response to PAF has been described from a number of animal preparations and purified human cells in vitro. Some of the acute bronchoconstriction in response to inhaled PAF in human subjects may be mediated by cysteinyl leukotrienes. ${ }^{56}$ Subsequent support for a direct contributory role for cysteinyl leukotrienes in the airway response to PAF in humans has been demonstrated by the marked inhibitory effect of selective cysteinyl leukotriene receptor antagonists, SKF 104353 and ICI 204219 on PAF-invoked bronchoconstriction. ${ }^{5758}$ Furthermore, an oral PAF antagonist, UK 74505, significantly attenuated PAF-invoked rises in urinary $\mathrm{LTE}_{4}$ levels. ${ }^{59}$

\section{Aspirin challenge}

Some subjects with asthma are intolerant of aspirin and other non-steroidal anti-inflammatory drugs, but the aetiology of this phenomenon remains unclear. One hypothesis is that inhibition of the cyclooxygenase enzyme provokes bronchoconstriction by the "shunting" of arachidonic acid towards metabolism by cellular lipoxygenases. In support of this, pretreatment of sensitised human bronchus in vitro with indomethacin generates increased $\mathrm{LTC}_{4}$ following immunological challenge. ${ }^{60}$ 
Furthermore, systemic provocation with aspirin in susceptible subjects results in the secretion of inflammatory mediators including leukotrienes into nasal lavage fluid. ${ }^{61}$ Increased urinary $\mathrm{LTE}_{4}$ excretion has now been observed in aspirin sensitive asthmatic subjects following both ora $1^{6263}$ and inhalational ${ }^{32}$ challenge. However, pretreatment of subjects with indomethacin in doses which were markedly inhibitory towards cyclooxygenase ${ }^{35}$ did not further enhance allergen-invoked bronchoconstriction or urinary $\mathrm{LTE}_{4}$ excretion, suggesting that the mechanism of aspirin-induced asthma is not directly related to "shunting" of arachidonate metabolism. Several studies have now shown significantly increased basal excretion of urinary $\mathrm{LTE}_{4}$ in aspirin sensitive asthmatic subjects compared with those who are not aspirin intolerant and normal subjects, ${ }^{326264}$ but the significance of this is unclear.

EVIDENCE OF CYSTEINYL LEUKOTRIENE RELEASE DURING DISEASE EXACERBATIONS

Taylor et $a l^{33}$ initially observed increases in urinary $\mathrm{LTE}_{4}$ levels in 24 hour urine collections in patients admitted to hospital with acute severe asthma, although there was a substantial overlap of urinary $\mathrm{LTE}_{4}$ measurements into the normal range. Furthermore, whilst urinary $\mathrm{LTE}_{4}$ levels tended to decrease during disease remission, this did not reach statistical significance. Drazen et $a t^{55}$ further evaluated the role of cysteinyl leukotrienes in patients presenting with acute airways obstruction. Urinary $\mathrm{LTE}_{4}$ excretion was significantly higher in those patients classified as "responders" (determined on the basis of airway reversibility to a nebulised $\beta_{2}$ agonist) compared with "non-responders" and normal volunteers. This provides strong support for a bronchoconstrictor role for cysteinyl leukotrienes in acute severe asthma, particularly in those patients in whom bronchoconstriction per se (and, by inference, heightened bronchodilator responsiveness) is a major component of their airways obstruction.

EVIDENCE FOR CYSTEINYL LEUKOTRIENE RELEASE UNDER BASAL CONDITIONS

Recent evidence ${ }^{2666-68}$ suggests that basal airway tone in asthmatic subjects is influenced by endogenous cysteinyl leukotrienes and may be responsible, at least in part, for persistent bronchoconstriction. For example, raised levels of cysteinyl leukotrienes have been demonstrated in BAL fluid before endobronchial allergen challenge in atopic asthmatic subjects compared with control groups. ${ }^{26}$ Further, the cysteinyl leukotriene receptor antagonists, ICI 204219 and MK-571, and the hydroxyamic acid 5-lipoxygenase inhibitor, zileuton, have shown significant acute bronchodilator effects in asthmatics of moderate severity. ${ }^{66-68}$ Whilst these observations have been supported in preliminary, albeit prolonged, dosing studies in chronic asthma, ${ }^{67-69}$ neither MK-571 nor ICI 204219 significantly improved pulmonary function prior to exercise challenge although this may have been a reflection of the mild airways obstruction in the population of patients studied. ${ }^{489}$ Baseline observations of urinary $\mathrm{LTE}_{4}$ excretion have also provided some useful information. A recent study has reported increased excretion of $\mathrm{LTE}_{4}$ in overnight urine samples in patients with nocturnal asthma which correlated with the magnitude of the morning dip. ${ }^{70}$ By contrast, Westcott et $a l^{\beta 8}$ found no correlation between baseline measurements of $\mathrm{FEV}_{1}$ and urinary $\mathrm{LTE}_{4}$ levels, and others have found no difference in urinary $\mathrm{LTE}_{4}$ excretion between asthmatic and non-asthmatic subjects under basal unchallenged conditions. ${ }^{3345}$

\section{Therapeutic intervention}

If cysteinyl leukotrienes play a significant part in the pathogenesis of asthma, then attempts to modulate their pharmacological actions should be of some therapeutic benefit. Clarification of the role of cysteinyl leukotrienes in asthma has to date focused on three therapeutic strategies: (1) dietary provision of alternative fatty acid substrates within membrane phospholipids thereby yielding products with less proinflammatory activity ${ }^{71}$ this approach has been largely unsuccessful ${ }^{72}$ and will not be discussed further; (2) pharmacological inhibition of specific synthetic enzymes, particularly 5-lipoxygenase, and (3) modulation of end organ effects with selective cysteinyl leukotriene receptor antagonists. The remainder of this review will concentrate on these latter two approaches, with emphasis on the effect of these classes of drugs on indirect bronchoconstrictor challenges administered to the airway, and their effect in chronic persistent asthma itself, rather than a discussion of those studies in which antagonism of leukotrienes has been evaluated.

\section{5-LIPOXYGENASE INHIBITION}

Early efforts to examine the efficacy of 5-lipoxygenase inhibitors failed to show any therapeutic benefit ${ }^{73-75}$ or evidence of adequate enzyme blockade. Zileuton (A-64077), an oral hydroxamic acid 5-lipoxygenase inhibitor, ${ }^{76}$ has proved more encouraging. Following nasal allergen challenge, symptoms of nasal congestion and $\mathrm{LTB}_{4}$ concentrations in nasal lavage fluid were significantly reduced although cysteinyl leukotriene concentrations were not evaluated. ${ }^{40}$ In a separate study zileuton significantly ameliorated the bronchoconstriction invoked by cold dry air. ${ }^{47}$ In contrast, when administered three hours before inhaled allergen challenge, zileuton did not significantly attenuate either early or late allergen-invoked bronchoconstriction or the allergen-invoked airway hyperresponsiveness. ${ }^{77}$ Although urinary $\mathrm{LTE}_{4}$ excretion was reduced by almost $50 \%$, the lack of clinical effect in the airway may have been related to insufficient inhibition of 5-lipoxygenase. ${ }^{77}$ However, zileuton has shown significant acute bronchodilator effects in moderately severe asthmatic patients and in preliminary chronic dosing studies. ${ }^{68} \mathrm{~A}$ further therapeutic target has been to antagonise the regulatory protein 5-lipoxygenase activating 
protein (FLAP), since expression of both 5lipoxygenase and FLAP are necessary for cellular leukotriene synthesis. ${ }^{7879}$ To date only one FLAP antagonist, MK-886, has progressed to clinical trials in laboratory-provoked airways obstruction. Whilst demonstrating marked attenuation of both early and late allergen-invoked bronchoconstriction and urinary $\mathrm{LTE}_{4}$ excretion, ${ }^{80}$ no effect was seen on the allergeninvoked increase in airways responsiveness although this may have been a reflection of the study design.

\section{CYSTEINYL LEUKOTRIENE RECEPTOR ANTAGONISM}

As with the early 5-lipoxygenase inhibitors, initial studies with cysteinyl leukotriene antagonists (L-649 923, LY-171 883, and L648051 administered orally ${ }^{8182}$ or by inhalation ${ }^{83}$ in standard allergen provocations were disappointing. The development of more potent and selective second generation cysteinyl leukotriene receptor antagonists (MK571, ICI 204 219, SK\&F 104353, RG12525) administered either by inhalation, oral or intravenous routes have proved more encouraging both in laboratory-provoked airway narrowing and in clinical asthma itself. Numerous recent studies have demonstrated their inhibitory effect against aspirin, ${ }^{84}$ PAF, $^{5758}$ allergen, ${ }^{418586}$ and (despite the contradictory evidence from direct mediator measurements $\mathrm{s}^{36434}$ ), exercise challenge. ${ }^{48-51}$ For example, Manning $e t ~ a l,{ }^{48}$ using the highly potent and selective intravenous $\mathrm{LTD}_{4}$ receptor antagonist, MK-571, showed significant attenuation of both the magnitude and duration of exercise-induced bronchoconstriction, suggesting an important role for $\mathrm{LTD}_{4}$ in this condition. A similar observation has been reported with the equally potent $\mathrm{LTD}_{4}$ receptor antagonist ICI 204219 when administered orally before exercise challenge. ${ }^{49}$ Furthermore, despite its modest effect following allergen-induced bronchoconstriction, ${ }^{81}$ LY 171883 reduced the bronchospastic response to hyperventilation of isocapnic cold air, suggesting that cysteinyl leukotrienes are involved in this response. ${ }^{50}$ Administration of an oral dose of ICI 204219 two hours before allergen challenge significantly attenuated both allergen-induced early and late bronchoconstrictor responses and the allergen-invoked increase in airways reactivity. ${ }^{41} \mathrm{~A}$ subsequent study with an inhaled preparation of the same drug inhibited only the early bronchoconstriction following allergen administration; ${ }^{87}$ the discrepancy in effects of the different routes of administration were thought to reflect different pharmacokinetic and pharmacodynamic profiles. Two further studies of different design have shown that, following ingestion of ICI 204219 , increased doses of allergen were required to provoke comparable bronchoconstriction to those observed on the placebo limb. ${ }^{85} 86$ Finally, intravenous administration of MK-571 resulted in a dose-related inhibition of allergen-induced bronchoconstriction ${ }^{88}$ and inhalation of SK\&F 104353 significantly inhibited the broncho- constriction invoked by $\mathrm{PAF},{ }^{57}$ exercise, ${ }^{51}$ and aspirin $^{84}$ in susceptible subjects.

As previously discussed, cysteinyl leukotrienes may contribute to resting bronchomotor tone in asthmatic subjects. Both ICI 204219 and MK-571 have acute bronchodilator actions additive to those of inhaled salbutamol in patients with moderately severe asthma ${ }^{6667} \mathrm{By}$ contrast, in subjects requiring only occasional use of $\beta_{2}$ agonist bronchodilators and in whom the airways limitation is minimal, these drugs appear to have little effect on basal airway tone. ${ }^{484}$

Effects of cysteinyl leukotriene antagonists in chronic asthma have also been reported. Dosing with LY 171883 for six weeks resulted in a modest rise in airway calibre which was associated (in a subpopulation of patients) with a significant reduction in $\beta_{2}$ agonist usage. ${ }^{89}$ Similar data with more potent receptor antagonists (ICI $204219,{ }^{69} \mathrm{MK}-571,{ }^{67}$ and RG $12525^{90}$ ), administered for up to six weeks, have also shown an improvement in airway physiology and symptom scores in patients with asthma.

\section{Conclusions}

The clinical entity of asthma is now known to comprise a combination of separate but intimately related pathophysiological processes including variable airways obstruction, bronchial hyperresponsiveness, and inflammation of the airways. The initiation and propagation of inflammation of the airways results from the coordinated collaboration of numerous inflammatory cells (resident in, or recruited to, the airway) and their cellular products. Whilst many would agree that no single inflammatory mediator is responsible for all the clinical and pathological events in bronchial asthma, there is now substantial evidence that the cysteinyl leukotrienes play an important part in the pathophysiology of the disease. Not only are they capable of reproducing many of the functional and histological features of asthma, there is now abundant literature on their release, both in acute severe asthma and following laboratory-provoked bronchoconstrictor challenges, and on their contribution to the resting bronchomotor tone in asthmatic patients.

Even when analytical approaches can be trusted to generate good quality data, it is important to interpret data correctly, particularly when invoking mechanistic roles for cysteinyl leukotrienes in mediating indirect bronchoconstriction. Such interpretation of mechanistic events in vivo is important, given that apparently conflicting evidence may arise from either pharmacological modulation of a physiological response when compared with direct mediator measurements in biological matrices (such as plasma, urine or bronchoalveolar lavage) during the response. The translation from identification of a putative mechanism to a useful therapeutic role is often not conclusive and further corroborative evidence should, if possible, be sought.

Present therapeutic strategies in asthma have two aims: (1) attenuation of airways in- 
flammation, and (2) promotion of bronchodilation. ${ }^{91}$ In this context it seems apposite to examine the capabilities of pharmacological agents which potently inhibit cysteinyl leukotriene synthesis or selectively antagonise their end organ effects and to determine how these may be disease modifying in asthma. The British Thoracic Society recently updated their guidelines for the management of both acute severe and chronic persistent asthma ${ }^{92}$ in which they advocate the use of inhaled glucocorticoids as first line anti-inflammatory therapy for all but the mildest of asthmatic patients. Further, of the currently available bronchodilators in clinical use, selective $\beta_{2}$ adrenergic agonists are by far the most effective. It is therefore against these therapies that mediator antagonists or synthesis inhibitors must be evaluated. Whilst 5-lipoxygenase inhibitors and cysteinyl leukotriene antagonists have demonstrable protective effects against many bronchoprovocative insults and can promote bronchodilation, it is clear that further clinical studies are required before they can be added to, or replace, existing therapy for asthma. To date, there have been few clinical studies evaluating the putative anti-inflammatory properties of these drugs, in contrast to the many clinical and histological studies with glucocorticoids in asthmatic patients across a wide spectrum of disease severity ${ }^{93}$ Furthermore, whether 5-lipoxygenase inhibitors and cysteinyl leukotriene receptor antagonists will induce changes of sufficient magnitude in airways reactivity to be considered disease modifying still remains unanswered. Nevertheless, if further studies in chronic persistent asthma confirm the current promising evidence, then agents which pharmacologically modulate the in vivo actions of cysteinyl leukotrienes should provide an additional therapeutic approach for the treatment of asthma.

This paper was commissioned and funded by Zeneca Pharmaceuticals Ltd.

1 Samuelsson B. Leukotrienes: mediators of immediate hypersensitivity reactions and inflammation. Science 1983; 220:568-75.

2 Lewis RA, Austen KF. The biologically active leukotrienes. f Clin Invest 1984;73:889-97.

3 Lewis RA, Austen KF, Soberman RJ. Leukotrienes and other products of the 5-lipoxygenase pathway. $N$ Engl $\mathcal{F}$ Med 1990;323:645-55.

4 Barnes PJ, Chung KF, Page CP. Inflammatory mediators and asthma. Pharmacol Rev 1988;40:49-84.

5 Piacentini GL, Kaliner MA. The potential roles of leukotrienes in bronchial asthma. Am Rev Respir Dis 1991;143. S96-9.

6 Arm JP, Lee TH. Sulphidopeptide leukotrienes in asthma. Clin Sci 1993;84:501-10.

7 Dahlen S-E, Hansson G, Hedquist P, Bjorck T, Granstrom $E$, Dahlen $B$. Allergen challenge of lung tissue from asthmatics elicits bronchial contraction that correlated with the release of leukotrienes $\mathrm{C}_{4}, \mathrm{D}_{4}$ and $\mathrm{E}_{4}$. Proc Natl Acad the release of leukotrienes

8 MacGlashan DW, Schleimer RP, Peters SP, Schulman ES MacGlashan DW, Schleimer RP, Peters SP, Schulman ES,
Adams GK, Newball HH, et al. Generation of leukotrienes Adams $\mathrm{GK}$, Newball $\mathrm{HH}$, et al. Generation of leukotrienes
by purified human lung mast cells. $\mathcal{F}$ Clin Invest 1982;70: by purified.

9 Weller PF, Lee CW, Foster DW, Corey EJ, Austen KF, Lewis PA. Generation and metabolism of 5-lipoxygenase pathway leukotrienes by human eosinophils: predominan production of leukotriene $\mathrm{C}_{4}$. Proc Natl Acad Sci USA 1983;80:7626-30.

10 Dahlen S-E. Leukotrienes as mediators of airway obstruction and bronchial hyperresponsiveness. In: Barne PJ, Rodger IW, Thomson NC, eds. Asthma: basic mechanisms and clinical management. Oxford: Blackwells, 1988: 188-205.

11 Weiss JW, Drazen JM, McFadden ER, Weller P, Corey EJ, Lewis RA, et al. Airway constriction in normal humans produced by inhalation of leukotriene $\mathrm{D}$ : potency, time course and effect of aspirin therapy. $\mathcal{F} A M A$ 1983;249: 2814-7.

12 Barnes NC, Piper PJ, Costello JF. Comparative effects of inhaled leukotriene $\mathrm{C}_{4}$, leukotriene $\mathrm{D}_{4}$, and histamine in normal human subjects. Thorax 1984;39:500-4.

13 Drazen JM, Austen KF. Leukotrienes and airway responses. Am Rev Respir Dis 1987;136:985-98.

14 Griffin M, Weiss JW, Leitch AG, McFadden ER, Corey EJ, Austen KF, et al. Effects of leukotriene D on the airways in asthma. N Engl f Med 1983;308:436-9.

15 Arm JP, Spur BW, Lee TH. The effects of inhaled LTE $_{4}$ on the airway responsiveness to histamine in subjects with asthma and normal subjects. F Allergy Clin Immunol 1988; 82:654-60.

16 O'Hickey SP, Arm JP, Rees PJ, Spur BW, Lee TH. The relative responsiveness to inhaled leukotriene $\mathrm{E}_{4}$, methacholine and histamine in normal and asthmatic subjects. Eur Respir f 1988;1:913-7.

17 Kaye MG, Smith LJ. Effects of inhaled leukotreiene $D_{4}$ and platelet activating factor on airway reactivity in normal platelet activating factor on airway reactivity
subjects. Am Rev Respir Dis 1990;141:993-7.

18 Phillips GC, Holgate ST. Interaction of inhaled LTC $_{4}$ with histamine and $\mathrm{PGD}_{2}$ on airway calibre in asthma. $\mathcal{f} A p p l$ Physiol 1989;66:304-12.

19 Creticos PS, Peters SP, Adkinson NF, Nacleiro RM, Hayes EC, Norman PS, et al. Peptide leukotriene release after antigen challenge in patients sensitive to ragweed. $N$ Engl M Med 1984;310:1626-30.

20 Nacleiro RM, Barody FM, Togias AG. The role of leukotrienes in allergic rhinitis: a review. Am Rev Respir Dis 1991;143:S91-5.

21 Van Vyve TM, Chanez P, Bousquet J, Lacoste JY, Michel FB, Godard P. Safety of bronchoalveolar lavage and bronchial biopsies in patients with asthma of variable severity. $\mathrm{Am}$ Rev Respir Dis 1992;146:116-21.

22 Walters EH, Gardiner PV. Bronchoalveolar lavage as a research tool. Thorax 1991;46:613-8.

23 Lam S, Chan H, Leriche JC, Chan-Yeung M, Salari H. Release of leukotrienes in patients with bronchial asthma. $\mathfrak{7}$ Allergy Clin Immunol 1988;81:711-7.

24 Wardlaw AJ, Hay H, Cromwell O, Collins JW, Kay AB. Leukotrienes, $\mathrm{LTC}_{4}$ and $\mathrm{LTB}_{4}$ in bronchoalveolar lavage in bronchial asthma and other respiratory diseases. $f$ Allergy Clin Immunol 1989;84:19-26.

25 Diaz P, Gonzalez MC, Galleguillos FR, Ancic P, Cromwell $\mathrm{O}$, Shepherd $\mathrm{D}$, et al. Leukocytes and mediators in bronchoalveolar lavage during allergen-induced late phase asthmatic reactions. Am Rev Respir Dis 1989;139:1383-9.

26 Wenzel E, Larsen GL, Johnston K, Voelkel BF, Westcott JY. Elevated levels of leukotriene $\mathrm{C}_{4}$ in bronchoalveolar lavage fluid from atopic asthmatics after endobronchial ave respir Dis 1990;142:112-9.

27 Kumlin M, Dahlen S-E. Characteristics of formation and further metabolism of leukotrienes in the chopped human lung. Biochim Biophys Acta 990;1044:201-10.

28 Orning L, Kaijser L, Hammarstrom S. In vivo metabolism of leukotriene $\mathrm{C}_{4}$ in man: urinary excretion of leukotriene $\mathrm{E}_{4}$. Biochem Biophys Res Commun 1985;130:214-20

29 Maltby NH, Taylor GW, Ritter JM, Moore KM, Fuller $\mathrm{RW}$, Dollery CT. Leukotriene $\mathrm{C}_{4}$ elimination and metabolism in man. $\mathcal{f}$ Allergy Clin Immunol 1990;85:3-9.

30 Sala A, Voekel NF, Maclouf J, Murphy RC. Leukotrienne $\mathrm{E}_{4}$ elimination and metabolism in normal human subjects. F Biol Chem 1990;265:21771-8.

31 Verhagen J, Bel E, Kijne GM, Sterk PJ, Bruynzeel PLB, Veldink GA, et al. The excretion of leukotriene $\mathrm{E}_{4}$ into urine following inhalation of leukotriene $\mathrm{D}_{4}$ by human urine following inhalation of leukotriene $\mathrm{D}_{4}$ by human
individuals. Biochem Biophys Res Commun 1987;148:864 8 .

32 Kumlin M, Dahlen B, Bjorck T, Zetterstrom O, Granstrom $E$, Dahlen SE. Urinary excretion of leukotriene $E_{4}$ and 11-dehydrothromboxane $B_{2}$ in response to bronchial provocation with allergen, aspirin, leukotriene $\mathrm{D}_{4}$ and histamine in asthmatics. Am Rev Respir Dis 1992;146:96-103.

33 Taylor GW, Taylor I, Black P, Maltby NH, Turner N, Fuller $\mathrm{RW}$, et al. Urinary leukotriene $\mathrm{E}_{4}$ after antigen challenge and in acute asthma and allergic rhinitis. Lancet 1989;i: and in 78 .

34 Manning PJ, Rokach J, Malo J-L, Ethier D, Cartier A Girard $\mathrm{Y}$, et al. Urinary leukotriene $\mathrm{E}_{4}$ levels during early and late asthmatic responses. $\mathcal{F}$ Allergy Clin Immunol 1990; 86:211-20.

35 Sladek K, Dworski R, FitzGerald GA, Buitkus KL, Block FJ, Marney SR Jr, et al. Allergen-stimulated release of thromboxane $\mathrm{A}_{2}$ and leukotriene $\mathrm{E}_{4}$ in humans. Am Rev Respir Dis 1990;141:1441-5.

36 Smith CM, Christie PE, Hawksworth RJ, Thien F, Lee TH. Urinary leukotrine $\mathrm{E}_{4}$ levels after allergen and exercise challenge in bronchial asthma. Am Rev Respir Dis 1991; 144:1411-3.

37 Tagari P, Rasmussen JB, Delorme D, Girard Y, Eriksson LO, Charleson S, et al. Comparison of urinary leukotriene $\mathrm{E}_{4}$ and 16-carboxytetranordihydro leukotriene $\mathrm{E}_{4} \mathrm{ex}-$ $\mathrm{E}_{4}$ and 16-carboxytetranordihydro leukotriene $\mathrm{E}_{4}$ excretion in allergic asthmat

38 Westcott JY, Smith HR, Wenzel SE, Larsen GL, Thomas $\mathrm{RB}$, Felstein $\mathrm{D}$, et al. Urinary leukotriene $\mathrm{E}_{4}$ levels in patients with asthma: effect of airways reactivity and sodium cromoglycate. Am Rev Respir Dis 1991;143:1322-8. 39 Shaw RJ, Fitzharris P, Cromwell O, Wardlaw AJ, Kay AB Allergen-induced release of sulphidopeptide leukotrienes (SRS-A) and $\mathrm{LTB}_{4}$ in allergic rhinitis. Allergy 1985;40: $1-6$.

40 Knapp HR. Reduced allergen-induced nasal congestion and 
leukotriene synthesis with an orally active 5-lipoxygenase inhibitor. $N$ Engl $f$ Med 1990;323:1735-8.

41 Taylor IK, Effect of cysteinyl-leukotriene receptor antagonist ICI 204219 on allergen-induced bronchoconstriction and airway hyperactivity in atopic subjects. Lancet 1991;337: $690-4$

42 Iikura Y, Nagakura T, Walsh GM, Akimoto K, Kisida M, Kondou T, et al. Role of chemical mediators after antigen and exercise challenge in children with asthma. $\mathcal{F}$ Allergy Clin Immunol 1988;81:1050-5.

43 Broide DH, Eisman S, Ramdel JW, Ferguson P, Schwartz LB, Wasserman S. Airway levels of mast cell derived mediators in exercise induced asthma. Am Rev Respir Dis 1990;141:563-8.

44 Taylor IK, Wellings R, Taylor GW, Fuller RW. Urinary leukotriene $\mathrm{E}_{4}$ in exercise-induced asthma. $\mathcal{F}$ Appl Physiol 1992;73:743-8.

45 Kikawa $Y$, Miyanomae $T$, Inoue $Y$, Saito $M$, Nakai $A$ Shigematsu $\mathrm{Y}$, et al. Urinary leukotriene $\mathrm{E}_{4}$ after exercise challenge in children with asthma. $\mathcal{F}$ Allergy Clin Immunol 1992;89:1111-9.

46 Pliss LB, Ingenito EP, Ingram RH Jr, Pichurko B. Assessment of bronchoalveolar cell and mediator response to isocapnic hypernoea in asthma. Am Rev Respir Dis 1990;142:73-8.

47 Israel E, Dermarkarian R, Rosenberg M, Sperling R, Taylor $\mathrm{G}$, Rubin $\mathrm{P}$, et al. The effects of a 5-lipoxygenase inhibito on asthma induced by cold dry air. $N$ Engl f Med 1990 323:1740-4

48 Manning PJ, Watson RM, Margolskee DJ, Williams VC, Schwartz JI, O'Byrne PJ. Inhibition of exercise-induced bronchoconstriction by MK-571, a potent leukotriene $\mathrm{D}$ receptor antagonist. $N$ Engl f Med 1990;323:1736-9.

49 Finnerty JP, Wood-Baker R, Thomson H, Holgate ST. Role of cysteinyl-leukotrienes in exercise-induced asthma. Inhibitory effect of ICI 204219 , a potent leukotriene $D_{4}$ receptor antagonist. Am Rev Respir Dis 1992;145:746-9.

50 Israel E, Juniper EF, Callaghhan JT, Mathur PN, Morri MM, Dowell AR, et al. Effect of a leukotriene antagonist MM, Dowell AR, et al. Effect of a leukotriene antagonist LY 171883 on cold air induced bronchoconstriction

51 Robuschi M, Riva E, Fuccella LM, Vida E, Barnabi R Rossi M, et al. Prevention of exercise-induced bronchoconstriction by a new leukotriene antagonist (SK \&F 104353). Am Rev Respir Dis 1992;145:1285-8.

52 Cuss FM, Dixon CMS, Barnes PJ. Effect of inhaled platelet activating factor on pulmonary function and bronchial responsiveness in man. Lancet 1986;ii:189-92.

53 Rubin AE, Smith LJ, Patterson R. The bronchoconstrictor properties of platelet activating factor in humans. Am Rev Respir Dis 1987;136:1145-51.

54 Smith LJ, Rubin AE, Patterson R. Mechanism of platelet activating factor induced bronchoconstriction in humans. Am Rev Respir Dis 1988;137:1015-9.

55 Schellenberg RR. Airway responses to platelet activating factor. Am Rev Respir Dis 1987;136:S28-31.

56 Taylor IK, Ward PS, Taylor GW, Dollery CT, Fuller RW. Inhaled PAF stimulates leukotriene and thromboxane $\mathbf{A}_{2}$ production in humans. F Appl Physiol 1991;71:1396-402.

57 Spencer DA, Evans JM, Green SE, Piper PJ, Costello JF. Participation of the cysteinyl-leukotrienes in the acute bronchoconstrictor response to inhaled platelet activating factor in man. Thorax 1991;46:441-5.

58 Kidney JC, Ridge S, Chung KF, Barnes PJ. Inhibition of platelet activating factor-induced bronchoconstriction by the leukotriene $\mathrm{D}_{4}$ receptor antagonist ICI 204219 . Am Rev Respir Dis 1993;147:215-7.

59 O'Connor BJ, Uden S, Carty TJ, Eskra JD, Barnes PJ Chung KF. Inhibitory effect of UK 74505 a potent and specific platelet activating factor antagonist on airway and systemic responses to inhaled PAF in man. Am $\mathcal{F}$ Respir Crit Care Med 1994;150:35-40.

60 Undem BJ, Pickett WC, Lichtenstein LM, Adams GK The effect of indomethacin on immunologic release of histamine and sulphidopeptide leukotrienes from human bronchus and lung parenchyma. Am Rev Respir Dis 1987; 136:1183-7.

61 Ferreri NR, Howland WC, Stevenson DD, Spiegelberg HL. Release of leukotrienes, prostaglandins and histamine int nasal secretions of aspirin sensitive asthmatics during reaction to aspirin. Am Rev Respir Dis 1988;137:847-54.

62 Christie PE, Tagari P, Ford-Hutchinson AW, Charlesson S, Chee $\mathrm{P}$, Arm JP, et al. Urinary leukotriene $\mathrm{E}_{4}$ concentrations increase after aspirin challenge in aspirin sensitive asthmatic patients. Am Rev Respir Dis 1991;144: 1025-9.

63 Knapp HR, Sladek K, FitzGerald GA. Increased excretion of leukotriene $E_{4}$ during aspirin-induced asthma. $f \mathrm{Lab}$ Clin Med 1992;119:48-51.

64 Smith CM, Hawksworth RJ, Thien FCK, Christie PE, Lee TH. Urinary leukotriene $\mathrm{E}_{4}$ in bronchial asthma. Eur Respir f 1992;5:693-9.

65 Drazen JM, O'Brien J, Sparrow D, Weiss ST, Martins MA, Israel $\mathrm{E}$, et al. Recovery of leukotriene $\mathrm{E}_{4}$ from the urine of patients with airway obstruction. Am Rev Respir Dis 1992;146:104-8.

66 Hui KP, Barnes NC. Lung function improvement in asthma with a cysteinyl-leukotriene receptor antagonist. Lancet 1991;337:1062-3.

67 Gaddy JN, Margolskee DJ, Bush RK, Williams VC, Busse WW. Bronchodilation with a potent and selective leukotriene $\mathrm{D}_{4}\left(\mathrm{LTD}_{4}\right)$ receptor antagonist $(\mathrm{MK}-571)$ in patients with asthma. Am Rev Respir Dis 1992;146:358-63.
68 Israel E, Rubin P, Kemp JP, Grossman J, Pierson W, Siegel SC, et al. The effect of inhibition of 5-lipoxygenase by zileuton in mild-to-moderate asthma. Ann Intern Med 1993;119:1059-66.

69 Spector SL, Smith LJ, Glass M. Effects of six weeks of therapy with oral doses of ICI 204219 , a leukotriene D receptor antagonist, in subjects with bronchial asthma. Am $\mathcal{F}$ Respir Crit Care Med 1994;150:618-23.

70 Bellia V, Cuttitta G, Mirabella A, Profita M, Bonanno A Catania $\mathrm{G}$, et al. Urinary leukotriene $\mathrm{E}_{4}$ as a marker of nocturnal asthma. Am Rev Respir Dis 1992;145:A16.

71 Lee TH. Pharmacological modulation of leukotriene and platelet activating factor biosynthesis and activities by alternative dietary fatty acids. Clin Exp Allergy 1989;19: 15-23.

72 Arm JP, Horton CE, Mencia-Huerta J-M, House F Eiser NM, Clark TJH, et al. Effect of dietary supplementation with fish oil lipids on mild asthma. Thorax 1988;43:84-92.

73 Fujimura M, Sasaki N, Nakatsumi Y. Effects of a thromboxane synthase inhibitor (OKY-046) and lipoxygenase inhibitor (AA-861) on bronchial responsiveness to acetylcholine in asthmatic subjects. Thorax 1986;41:955-9.

74 Mann JS, Robinson C, Sheridan AQ, Clement P, Bach MK, Holgate ST. Effect of inhaled Piriprost (U-60,257), a novel leukotriene inhibitor, on allergen and exercise induced bronchoconstriction in asthma. Thorax 1986;41:746-52.

75 Fuller RW, Maltby N, Richmond R. Oral nafazatrom in man: effect on inhaled allergen challenge. $\mathrm{Br} f \mathrm{Clin}$ Pharmacol 1987;23:677-81.

76 Carter GW, Young PR, Albert D, Summers JB, Kim KH Holms JH, et al. Properties of A-64077, a new potent orally active 5-lipoxygenase inhibitor. Leukotrienes and prostanoids in health and disease. In: Zor U, Naor Z, Danon A, eds. New trends in lipid mediator research. Vol 3. Basel, Switzerland: Karger, 1989:50-5.

77 Hui KP, Taylor IK, Taylor GW, Rubin P, Kesterson J, Barnes NC, et al. Effect of a 5-lipoxygenase inhibitor on leukotriene generation and airway responses after allergen challenge in asthmatic patients. Thorax 1991;46:184-9.

78 Dixon RAF, Diehl RE, Opas E, Rands E, Vickers PJ, Evans JF, et al. Requirement of a 5-lipoxygenase activating protein for leukotriene synthesis. Nature (London) 1990 343:282-4.

79 Miller DK, Gillard JW, Vickers PJ, Sadowski S, Leveille C, Mancini JA, et al. Identification and isolation of a membrane protein necessary for leukotriene production. Nature (London) 1990;343:278-81.

80 Friedman BS, Bel EH, Tanaka W, Han YHR, Spector R, Sterk $P$. The effect of a leukotrienes biosynthesis inhibitor (MK-886) on allergen-induced bronchoconstriction and leukotriene production in asthmatic subjects. Am Rev leukotriene production in ast
Respir Dis 1993;147:839-44.

81 Fuller RW, Black PN, Dollery CT. Effect of the leukotriene antagonist LY 171883 on inhaled and intradermal challenge with antigen and leukotriene $\mathrm{D}_{4}$ in atopic subjects. f Allergy Clin Immunol 1989;83:939-44.

82 Britton JB, Hanley SP, Tattersfield AE. The effect of an oral leukotriene $\mathrm{D}_{4}$ antagonist L-649,923 on the response to inhaled antigen in asthma. F Allergy Clin Immunol 1987; 79:811-6.

83 Bel EH, Timmers MC, Dijkman JH, Stahl EG, Sterk PJ The effect of an inhaled leukotriene antagonist, L-648, 051 on early and late asthmatic reactions and subsequent increase in airway responsiveness in man. $\mathcal{F}$ Allergy Clin Immunol 1990;85:1067-75.

84 Christie PE, Smith CM, Lee TH. The potent and selective sulphidopeptide leukotriene antagonist SK\&F 104353 inhibits aspirin-induced asthma. Am Rev Respir Dis 1991 144:957-8.

85 Dahlen B, Zetterstrom O, Bjork T, Dahlen S-E. The leukotriene antagonist ICI 204219 inhibits the early airway reaction to cumulative bronchial challenge with allergen in atopic asthmatics. Eur Respir f 1994;7:324-31.

86 Findlopic asthmatics. Eur Respir $\mathcal{f}$ 1994,7.324-31. the oral leukotriene antagonist, ICI 204219 on antigeninduced bronchoconstriction in subjects with asthma. $\mathcal{f}$ Allergy Clin Immunol 1992;89:1040-5.

87 O'Shaughnessy KM, Taylor IK, O'Connor BJ, O'Connell F Thomson H, Dollery CT. Potent leukotriene $\mathrm{D}_{4}$ recepto antagonist ICI 204219 given by the inhaled route inhibits the early but not the late phase of allergen-induced bronchoconstriction. Am Rev Respir Dis 1993;147:1431-5.

88 Rasmussen JB, Eriksson L-O, Margolskee DJ, Tagari P, Williams VC, Andersson KE. Leukotriene $\mathrm{D}_{4}$ receptor blockade inhibits the immediate and late bronchoconstrictor responses to inhaled antigen in patients with constrictor responses to inhaled antigen in patien.

89 Cloud MC, Enas GC, Kemp J, Platts-Mills T, Altman LC, Townley R, et al. A specific $\mathrm{LTD}_{4} / \mathrm{LTE}_{4}$ receptor $\mathrm{LC}$, Townley $\mathrm{R}$, et al. A specific $\mathrm{LTD}_{4} / \mathrm{LTE}_{4}$ receptor antagonist improves pulmonary function in patients with 9 .

90 Wahendna I, Wisniewski AFZ, Wong CS, Tattersfield AE. Effect of multiple doses of RG 12525, an oral leukotriene $\mathrm{D}_{4}$ antagonist, in chronic asthma. Am Rev Respir Dis 1992, 145:A16.

91 Barnes PJ. A new approach to the treatment of asthma. $N$ Engl f Med 1989;321:1517-27.

92 British Thoracic Society. Guidelines on the management of asthma. Thorax 1993;48:S1-24.

93 Taylor IK, Shaw RJ. The mechanism of action of corticosteroids in asthma. Respir Med 1993;87:261-77. 